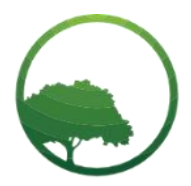

Research in Business \& Social Science

IJRBS VOL 10 NO 6 ISSN: 2147-4478

\title{
Legal protection justice collaborators in corruption justice system
}

\author{
(iD) Mochamad Ali Asgar (a) (iD I Nyoman Nurjaya ${ }^{(b)}$ (D) Bambang Sugiri (c) \\ (D) Tunggul Anshari ${ }^{(d)}$ \\ ${ }^{(a, b, c, c)}$ Faculty of Law, Brawijaya University, Veteran Street no. 1 Post code: 65125, Malang City, Indonesia
}

Crossref

A R T I C L E I N F O
Article history:
Received 22 August 2021
Received in rev. form 18 Sep. 202
Accepted 21 Sept 2021
Keywords:
Corruption, Legal Protection,
Collaborators, Criminal Justice.
JEL Classification:
K14, K20, K40, K33

\section{A R T ICLE INFO}

\begin{abstract}
A B S T R A C T
Corruption is a crime that is difficult to eradicate because the perpetrators of corruption usually have a strong economic and political position, so that corruption is classified as a white-collar crime, crimes as business, economic crimes, official crime and abuse of power. The purpose of this research is to know the urgency of providing legal protection for witnesses to perpetrators who are willing to cooperate with law enforcement in the investigation of Corruption Crimes. This research is a normative legal research using the statute approach, philosophical approach and case approach. The results can be explained that the urgency of providing legal protection for perpetrators of witnesses who are willing to cooperate with law enforcement in the investigation of Corruption Crimes because Justice Collaborator is the main actor who can help uncover a crime because it has the potential to have evidence to drag the main perpetrator and other suspects in. Third, the future arrangements for perpetrator witnesses who are willing to cooperate with law enforcement still cannot be used as a strong legal basis regarding the right of commutation of sentence for Justice Collaborators in criminal justice by law enforcement officers and many have weaknesses, especially in terms of commutation of sentences for Justice Collaborators for their testimonies in assisting law enforcement officers but are only used as considerations by judges without any binding power that obliges judges to provide leniency.
\end{abstract}

(C) 2021 by the authors. Licensee SSBFNET, Istanbul, Turkey. This article is an open access article distributed under the terms and conditions of the Creative Commons Attribution (CC BY) license

(http://creativecommons.org/licenses/by/4.0/). 
the case to law enforcement officers, this happens in several possibilities (Manalu, 2015). First, as a person who participates with other people in corruption. Second, people who commit corruption on the advice of people. Third, people who help others commit corruption.

The emergence of the existence of Justice Collaborator is based on several provisions in the 2003 United Nations Concention Against Corruption (UNCAC) preamble which has been ratified by Law Number 7 of 2006 concerning Ratification of the United Nations Convention Against Corruption (2003), which emphasizes that corruption as an extraordinary crime must be fought because it has a massive impact on the life of the country. So the eradication must be carried out in an extraordinary manner.

In national law, Justice Collaborator is regulated in Law Number 13 of 2006 as amended by Law Number 31 of 2014 concerning Protection of Witnesses and Victims, Circular Letter of the Supreme Court (SEMA) Number 04 of 2011, Joint Regulation of the Minister of Law and Human Rights Humans, the Attorney General, the Chief of the Indonesian National Police, the Corruption Eradication Commission, and the Witness and Victim Protection Agency (LPSK) regarding the Protection of Whistleblowers, Reporting Witnesses, and Collaborating Perpetrators.

Juridically normative based on Article 10 paragraph (2) of Law no. 13 of 2006 concerning the Protection of Witnesses and Victims, the existence of a Justice Collaborator has no place to obtain legal protection, meaning that there is no clear legal certainty for a Justice Collaborator. Even a witness who is also a suspect in the same case cannot be acquitted of criminal charges if he is legally and convincingly proven guilty, but his testimony can be taken into consideration by the judge in mitigating the sentence to be imposed, so that it does not guarantee protection for the Justice Collaborator. The Criminal Code (KUHP) and the Criminal Procedure Code (KUHAP) also do not completely regulate the position of Justice Collaborator.

Meanwhile, SEMA Number 4 of 2011 concerning Treatment of Criminal Whistleblowers (Whistle Blowers) and Witnesses of Cooperating Perpetrators or Justice Collaborators in Certain Criminal Acts number 9 letter a, justice collaborator is defined as a perpetrator of a certain crime, but not a perpetrator. the main person who admits his actions and is willing to be a witness in the judicial process, but the SEMA cannot bind the prosecutor or the investigator. The SEMA above is only an internal rule within the judiciary, so it does not have a strong authority in ensuring that justice collaborators get special treatment.

LPSK in protecting justice collaborators has an important role. LPSK noted that requests for protection from witnesses of corruption cases increase every year and some of them are categorized as justice collaborators. It can be seen that corruption can be a factor that is causally related to other factors, such as weak laws, depending on the context and position in a society (Alkostar, 2008). So that regulations related to corruption should not create gaps for power holders to abuse. In addition, institutions that play a role in enforcing corruption cases also play a very important role.

Based on data from the Corruption Eradication Commission, in 2016 there were 21 applications for suspects in Corruption Crimes asking for Justice Collaborator status at the Corruption Eradication Commission. Of the 21 applications, 2 cases were accepted as Justice Collaborators and 10 were rejected/not eligible and 9 applications are still in process. Meanwhile, according to LPSK data up to 2016 there were 8 cases where the suspect or defendant had obtained Justice Collaborator status from LPSK and was under LPSK protection. All of these cases are corruption cases. While data from the National Narcotics Agency (BNN) in 2016 there were 8 inmates who asked for the Justice Collaborator and all of them were rejected by BNN because they had never collaborated with investigators and some were never investigated by BNN (ICJR, 2016).

The condition of unclear regulations results in uncertainty, protection from Justice Collaborators and binding power to law enforcement, as can be seen from several cases at trial where the Corruption Eradication Commission (KPK) granted Justice Collaborator status to a number of suspected corruption cases including Agus Tjondro Prayitno (bribery case in the election of Senior Deputy Bank Indonesia) and Mindo Rosalina Manulang in the bribery case for the construction of the Athlete House, the Hambalang project, and the laboratory construction project at the Ministry of Education, the Krakatau Steel bribery case involving Kurniawan Eddy Tjokro alias Yudi Tjokro as President Director of PT. Tjokro Brothers, the E-KTP corruption case with the suspect Andi Narogong who is also a justice collaborator and the latest in the Setyo Novanto case. However, the panel of judges at the Corruption Court still sentenced them according to the amount of punishment demanded by the prosecutor even though the law stated that the Justice Collaborator's statement was considered by the judge to reduce the sentence.

Thus the norms of positive law do not provide a proper place for justice collaborators. The arrangements as mentioned above still do not provide proportional arrangements, so that the existence of justice collaborators can be responded to differently by law enforcers, causing problems both juridically and philosophically.

This study uses a normative legal research method by taking a statutory approach, a philosophical approach and a case approach.

i. Statute Approach, Researchers approach legislation to find out the basis for regulating Justice Collaborator as an effort to eradicate corruption and restore state finances, so that reformulation can be carried out.

ii. Phiosophica approach, This is done to find out and understand in depth the arguments for the Justice Collaborator.

iii. Case approach, conducted to find out the legal arguments for law enforcement in considering the status of Justice Collaborator in eradicating corruption. In this study the cases that became the object of research were the case of Agus 
Tjondro Prayitno (the bribery case for the election of a Senior Deputy of Bank Indonesia), Mindo Rosalina Manulang in the bribery case for the construction of the Wisma Atlet, the Hambalang project, and the laboratory construction project at the Ministry of Education, the E-KTP corruption case with suspect Andi Narogong who is also a justice collaborator and the latest in the Setyo Novanto case.

Legal materials in this study consist of primary legal materials, secondary legal materials and tertiary book materials. Each ingredient consists of (Soekanto, 2012):

i. Primary legal materials, namely binding legal materials, consist of the 1945 Constitution of the Republic of Indonesia; RI Law No. 8 of 1981 concerning the Criminal Procedure Code (KUHAP); the Criminal Code (KUHP); Law of the Republic of Indonesia Number 31 of 1999 as amended by Law of the Republic of Indonesia Number 20 of 2001 concerning the Eradication of Criminal Acts of Corruption; Law Number 31 of 2014 concerning amendments to Law Number 13 of 2006 concerning Protection of Witnesses and Victims; Supreme Court Circular (SEMA) No. 04 of 2011; and Joint Regulations of the Minister of Law and Human Rights, Attorney General, National Police Chief, KPK, and LPSK concerning Protection for Reporting Reporters, Reporting Witnesses, and Collaborating Perpetrator Witnesses;

ii. Secondary Legal Materials, namely reading materials or literature that can provide an explanation of primary legal materials in the form of legal books that are correlated with legal dictionaries, literature, and articles, including research related to the object to be studied. The researcher also conducted interviews with related parties including the Corruption Eradication Commission, the judges who examined the cases that were the object of research.

iii. Tertiary legal materials or non-legal materials are legal materials used as complementary materials related to restrictions on individual vehicles.

The method of collecting legal materials is carried out by means of a literature study (Library research) through deepening of books or literature and legal documents. The legal materials obtained are described and linked in such a way, so that they are presented in a more systematic writing in order to answer the problems that have been formulated (Ibrahim, 2006). Analysis of legal materials is carried out in an analytical prescriptive manner, namely deductive-inductive reasoning to produce legal figures as answers to problems or other research findings with the aim of producing what prescriptions should be the essence of legal research (Amiruddin, and Asikin, 2016). The results of the analysis using legal logic, legal arguments, legal principles that will produce conclusions as answers to problems that must be answered and use legal reasoning.

\section{Justice Collaborator}

\section{The Term of Justice Collaborator}

The use of the term justice collaborator varies between countries. Some use the words Cooperative Whistleblowers, Participant Whistleblowers, Collaborators with Justice or Pentiti (Italy) (Pramono, 2016). In Indonesia, based on the Circular Letter of the Supreme Court Number 4 of 2011 concerning the Treatment of Criminal Whistleblowers (Whistleblowers) and Witnesses of Cooperating Perpetrators (justice collaborators) in Certain Criminal Acts, provides a difference between the terms Whistleblower and justice collaborator. The reporting witness is called a Whistleblower, while the perpetrator witness who cooperates is called a Justice collaborator (Ilyas, 2018).

The term Whistleblowers is a new term in the Criminal Procedure Code in Indonesia. However, in Indonesia there is the term "crown witness" or crown witness, ie one of the perpetrators of a crime is drawn as a key witness to reveal the other perpetrators with the lure of reducing the threat of punishment. This system has long been implemented in Continental European countries such as the Netherlands, France, and Italy by using the concept of Protection of Cooperating Persons, while the Whistleblowers Concept is mostly promoted by Anglo Saxon countries, especially America and common health countries (Widjaya, 2012). Then the term justice collaborator is also the same as the perpetrator's witness as regulated in Law Number 13 of 2006 Junto Law Number 31 of 2014 concerning Protection of Witnesses and Victims. Article 1 paragraph (2) confirms that the perpetrator's witness is a suspect, defendant, or convict who cooperates with law enforcement to uncover a criminal act in the same case.

Atmasasmita (2011), distinguishes between Whistleblowers and Justice collaborators. Whistleblower is any person, usually a victim, who then testifies to provide information to investigators regarding the ins and outs of a criminal act that he knows and hears about himself, and even experiences it himself. With that he gets a guarantee of protection for security (physical) under the supervision of the police. You do this by changing your identity, placing it in a certain location and being under super-tight surveillance and the police intelligence. The purpose of the existence of a Whistleblower is to facilitate the task of investigators, so that a case can be fully disclosed to the intellectual-dader and the leadership of the crime organization.

\section{Legal Basis for Justice Collaborator Regulation}

Justice collaborators or witnesses to perpetrators who work together, have the risk of getting threats or furthermore becoming victims of murder. This is because a justice collaborator can assist law enforcement in an effort to find out, find clarity and uncover criminal acts, including the main perpetrators of a crime. Guidelines for determining a person as a witness to a cooperating perpetrator (justice collaborator) was first regulated in SEMA Number 4 of 2011 which was addressed to the Heads of High Courts and Heads of District 
Courts throughout Indonesia which was signed by the Chief Justice of the Supreme Court Harifin A. Tumpa, in Jakarta on August 10 2011. The guidelines are as follows:

i. The person concerned is one of the perpetrators of certain criminal acts as referred to in this SEMA, admits the crime he has committed, is not the main actor in the crime, and provides testimony as a witness in the judicial process;

ii. The Public Prosecutor in his charge states that the person concerned has provided information, and very significant evidence so that investigators and/or public prosecutors can uncover the said crime effectively, uncover other actors who have a greater role and/or return assets/ proceeds of crime.

Then on December 14, 2011 in Jakarta, a Joint Regulation of the Minister of Law and Human Rights, the Attorney General, the Chief of Police, the Corruption Eradication Commission, and the Head of the Witness and Victim Protection Agency Number: m.hh11.hm.03.02 were enacted. th.2011, Number: per-045/a/ja/12/2011, Number: 1 of 2011, Number kepb-02/01-55/12/2011, Number: 4 of 2011 concerning Protection for Whistleblowers, Reporting Witnesses, and Collaborating Perpetrator Witnesses. Based on the Joint Regulations, the conditions for obtaining protection as witnesses of cooperating perpetrators are as follows: The crime to be disclosed is a serious and/or organized crime; Provide significant, relevant and reliable information to uncover a serious and/or organized crime; Not the main perpetrator in the crime that will be disclosed; Willingness to return a number of assets obtained from the crime in question, which is stated in a written statement; There is a real threat or concern about the threat, pressure, both physically and psychologically against the witness of the perpetrator who cooperates or his family if the crime is revealed according to the actual situation.

Law Number 13 of 2006 in conjunction with Law Number 31 of 2014 concerning Protection of Witnesses and Victims, LPSK's Protection of Perpetrator Witnesses is provided with conditions. While the rights of Justice collaborators are spread across several laws and regulations as follows:

i. Law Number 7 of 2006 concerning Ratification of the United Nations Convention Against Corruption, 2003.

Article 32 confirms:

a. Each participating country is obliged to take appropriate actions in accordance with the legal system in force in its country, and by all means provide effective protection and the possibility of retaliation or threats/intimidation against witnesses and expert witnesses who testify about criminal acts determined in accordance with this convention, and to the extent necessary for their families and others close to them;

b. The actions described in paragraph (1) of this article may include: without (reducing or eliminating) the rights of the accused, including the right to a fair trial:

c. Determine procedures for the physical protection of such persons such as, to the extent necessary and possible relocating them and permitting, where appropriate (non-disclosure) or restrictions on the disclosure of information about the identity and whereabouts of such persons;

d. Provide a law of evidence that allows witnesses and experts to testify in a way that ensures the safety of these people, such as allowing testimony to be given using communication technology, video or other appropriate means.

e. The participating countries shall consider entering into agreements or arrangements with other countries regarding the relocation of persons as referred to in paragraph (1).

ii. Law Number 5 Year 2009 concerning Ratification of the Convention Against Transnational Organized Crimes/UNCATOC (UN Convention Against Transnational Organized Crime).

The legal protection of justice collaborators has been regulated in Article 24 paragraph (1) which states that "every state party is obliged to take appropriate measures within its capabilities, to provide effective protection and possible retaliation or intimidation against witnesses in criminal proceedings who testify about offenses set forth in this Convention and where appropriate for members of their families and other persons close to them."

iii. Law Number 13 of 2006 in conjunction with Law Number 31 of 2014 concerning Protection of Witnesses and Victims.

Regulations related to the rights of justice collaborators are regulated in several articles, namely:

Article 10

i. Witness, Victim, Witness Perpetrator, and/or Reporting Party cannot be legally prosecuted, both criminal and civil for the testimony and/or report that will be, is being, or has been given, unless the testimony or report is not given in good faith;

ii. In the event that there is a lawsuit against a Witness, Victim, Witness Perpetrator, and/or Reporting Party for the testimony and/or report that will be, is being or has been given, the lawsuit must be postponed until the case that he reports or he gives testimony has been decided by court and obtain permanent legal force.

Article $10 \mathrm{~A}$ 
i. Perpetrator witnesses may be given special treatment in the examination process and award for the testimony given;

ii. Specific handling as referred to in paragraph (1) in the form of:

a. Separation of places of detention or places of serving a crime between the perpetrator's witness and the suspect, defendant, and/or convict whose crime is revealed;

b. Separation of filings between the perpetrator's witness file and the suspect's and defendant's files in the process of investigation, and prosecution of the crimes he disclosed, and/or;

c. Giving testimony in front of the trial without dealing directly with the defendant whose crime was revealed.

iii. The award for the testimony as referred to in paragraph (1) is in the form of:

a. leniency of punishment, or

b. Conditional release, additional remission, and the rights of other prisoners in accordance with the provisions of the legislation for Perpetrator Witnesses who are inmates with the status of Prisoners.

iv. Government Regulation Number 99 of 2012 concerning Terms and Procedures for the Implementation of the Rights of Correctional Inmates.

The requirements for granting remissions for perpetrators of corruption have been added and tightened in PP No. 99 of 2012 for prisoners convicted of criminal acts of terrorism, narcotics, corruption, crimes against state security, serious human rights crimes and other transnational organized crimes (Rais, 1999). Conditions for granting remission for perpetrators of corruption can only be given to prisoners who are willing to cooperate with law enforcement to help dismantle criminal cases they have committed (justice collaborator) and have paid the fine and compensation in full in accordance with court decisions.

vi. Joint Regulation Number: m.hh-11.hm.03.02.th.2011, Number: per-045/a/ja/12/2011, Number: 1 of 2011, Number: kepb02/01-55/12/ 2011, Number: 4 of 2011 concerning Protection for Whistleblowers, Reporting Witnesses and Co-operating Perpetrators. Witnesses of perpetrators who cooperate are entitled to physical and psychological protection; Legal protection; Special handling.

vii. SEMA Number 4 of 2011 concerning the Treatment of Whistleblowers and Judicial Collaborators in Certain Criminal Cases.

With the help of a justice collaborator, the Judge in passing a criminal decision as referred to in Article 9 point $\mathrm{C}$, can be in the form of: Imposing a special conditional probationary sentence; and/or Imposing a punishment in the form of the lightest punishment among other defendants who are proven guilty in the case in question.

\section{Mechanism of Granting Justice Collaborator's Rights}

Samendawai (2013) suggests the mechanism for granting justice collaborator rights as follows:

i. Mechanism of providing physical and psychological protection

a. The granting process is facilitated by LPSK on the initiative of a request for protection that is submitted (can) come from a justice collaborator or other law enforcement agency, after the Attorney General or the KPK has determined the person as a justice collaborator;

b. It is not possible for the suspect/defendant to directly apply for protection to the LPSK if the status as a justice collaborator has not been determined;

c. LPSK conducts an examination process for the fulfillment of all requirements which then, LPSK must, either alone or with the support of other parties, provide physical and psychological protection for justice collaborators.

ii. Mechanism of giving special treatment

a. Regarding the provision of protection in the form of placing a separate detention room from other perpetrators in the case he disclosed, LPSK coordinates with the party conducting the institution that has the authority to handle detention (Ministry of Law and Human Rights);

b. With regard to delays in legal proceedings arising from the information, reports and/or testimonies provided, there is no need for setting up a special mechanism to obtain them, because it has been regulated in the Law that there is an obligation for law enforcement officers to do so;

c. This should have been automatically done by law enforcement officials, unless there are conditions where it cannot be done.

iii. Award Mechanism

a. The awarding process is made in the form of a contract between the public prosecutor and the justice collaborator;

b. The application can be submitted by the justice collaborator himself or through law enforcement officers who handle the case; 
c. Applications can be submitted directly to the highest officials in the field of prosecution, both the Attorney General and the KPK (related to corruption), LPSK can provide recommendations to the Attorney General or the Chair of the KPK regarding this matter;

d. Specifically for awarding justice collaborators in the form of remissions and pardons, the role of the Attorney General or the Chairperson of the KPK is only to give consideration to the Minister of Law and Human Rights and the President.

\section{Fulfilling the Rights of Justice Collaborators in Corruption Cases in Indonesia}

Corruption is an organized crime (Alt and Lessen, 2010). It is said to be organized because the perpetrators usually come from people who hold power and have strategic positions, both in the executive, legislative and judicial branches (Husodo, 2016). Adji (2009) stated that in a comprehensive context, it is undeniable that corruption is a white-collar crime with actions that always experience a dynamic modus operandi from all sides, so that it is said to be an invisible crime which is very difficult to obtain procedural proof. The matter of the difficulty of opening the modus operandi of this organized crime, in the development of law enforcement in the future is also carried out in an extraordinary way. Breakthroughs introduced in proving the crime, namely through the disclosure of crimes involving the perpetrators of the crime themselves. This is what is called a cooperating perpetrator witness (justice collaborator).

Regarding the regulation of justice collaborators in the prosecution of criminal acts of corruption, Article 32 of the United Nations Convention Against Corruption (2003) as ratified into Law Number 7 of 2006 also affirms "every participating country is obliged to provide protection physically and psychologically against witnesses and experts in disclosing corruption." Furthermore, the next Article 37 also stipulates awards for cooperating perpetrator witnesses, including:

i. Each State Party shall consider, providing the possibility in certain cases to reduce the sentence of a perpetrator who provides substantial cooperation in the investigation or prosecution of a crime of corruption;

ii. Each participating country must consider the possibility in accordance with the basic principles of its national law to grant immunity and prosecution for persons who provide substantial cooperation in the investigation or prosecution (justice collaborator) of a criminal act of corruption. Legal protection for cooperating perpetrator witnesses.

In general, the placement of an actor who is willing to cooperate in the law is called a witness to the perpetrator (justice collaborator). Perpetrator witnesses in a prosecution are always supported by two complementary mechanisms and are used in parallel, which can be given both at the beginning of a criminal investigation until a court decision, even until the decision is handed down (Napitupulu, 2014). Things that can be given to justice collaborators or in other words the fulfillment of the rights of justice collaborators in corruption cases in the criminal justice system are divided into several points, including: protection, special handling, and awarding.

\section{Protection}

i. Physical Protection

The Corruption Eradication Commission as a state institution established based on Law Number 30 of 2002 concerning the Corruption Eradication Commission which based on Article 15 letter (a) asserts that "KPK is obliged to provide protection to witnesses or whistleblowers who submit reports or provide information regarding the occurrence of criminal acts. corruption crime." However, legal protection does not have absolute exceptions and does not apply to witnesses or reporters involved in corruption offenses. Therefore, the principle of lex certa is a binding norm that cannot be interpreted otherwise and the purpose for which the substance of the norm is regulated. Article 31 of Law Number 31 of 1999 and its Elucidation do not provide legal protection for witnesses and reporters involved in corruption offenses.

The KPK, in accordance with Article 15 of Law Number 30 of 2002 and its Elucidation, is obliged to provide protection for Witnesses and Reporters regarding the occurrence of criminal acts of corruption. However, this protection principle is physical protection (security, evacuation or identity change), besides of course the protection only applies to non-criminal person protection, meaning that it does not apply to witnesses or reporters who are indeed involved in allegations of corruption.

LPSK which was born based on Law Number 13 of 2006 in conjunction with Law Number 31 of 2014 concerning the Protection of Witnesses and Victims affirms the rights of witness perpetrators:

a. Obtain protection for personal, family and property security and be free from threats related to the testimony that will be, is being or has been given;

b. Participate in the process of selecting and determining the form of security protection and support;

c. Provide information without pressure;

d. Get a translator;

e. Free from ensnaring questions;

f. Obtain information regarding the development of the case;

g. Obtain information about court decisions;

h. Knowing in case the convict is released; 
i. His identity is kept confidential;

j. Get a new identity;

k. Obtaining temporary residence;

1. Get a new place of residence;

m. Obtain reimbursement of transportation costs as needed;

n. Get legal advice;

o. Obtain temporary living expenses assistance until the protection period ends;

p. Get assistance;

q. Cannot be prosecuted by law, both criminal and civil for the testimony and/or report that will be, is being or has been given, unless the testimony or report is not given in good faith;

r. In the event that there is a lawsuit against the testimony and/or report that will be, is being or has been given, the lawsuit must be postponed until the case he reports or he gives testimony has been decided by the court and has permanent legal force.

The rights mentioned above can then also be grouped into protection services and procedural rights support services. The role of LPSK in classifying the rights of witnesses and victims, as a further series of procedural rights services, consists of: providing information without pressure, getting an interpreter, being free from entangling questions, getting information about the progress of the case, getting information about court decisions, getting information in the convict is released, obtains transportation costs reimbursement according to his needs, and gets legal advice.

Determination of justice collaborator in essence must follow the standards that have been determined in the Act. This is confirmed in Article 28 paragraph (2) of Law Number 31 of 2014 which stipulates that the protection of LPSK for Perpetrator Witnesses is given on the basis of the following considerations:

a. The crime to be disclosed is a crime in certain cases according to the LPSK's decision as referred to in Article 5 paragraph (2);

b. The nature of the importance of the information provided by the Perpetrator Witness in revealing a criminal act;

c. Not as the main actor in the crime he disclosed;

d. Willingness to return assets obtained from criminal acts committed and stated in a written statement; and

e. There is a real threat or concern that there will be threats, physical or psychological pressure on the Witness Perpetrator or his Family if the crime is revealed according to the actual situation.

Thus, the Corruption Eradication Commission will not immediately grant a request or ask someone to become a justice collaborator.

ii. Legal Protection

A witness to the perpetrator in providing information to law enforcement regarding a criminal act that will be revealed often experiences back reports from the parties he mentions. On this basis, the government provides legal protection for both the perpetrator's witness (justice collaborator) and the reporting witness (Whistleblower).

Legal protection for the Reporting Witness was originally regulated before the issuance of Law Number 13 of 2006 in conjunction with Law Number 31 of 2014 concerning Protection of Witnesses and Victims, which is contained in the explanation of Article 15 letter (a) further stating that "What is meant by "providing protection is This provision also includes providing security guarantees by requesting police assistance or changing the identity of the reporter or carrying out evacuations including legal protection."

While Article 41 paragraph (2) letter e of Law Number 31 of 1999 confirms that "the right to obtain legal protection in terms of implementing (a) the right to seek, obtain, and provide information on allegations of corruption, (b) the right to obtain services in seeking, obtaining, and providing information on allegations of corruption having occurred to law enforcers who handle corruption cases; As well as being asked to be present in the process of investigation, investigation, and in court as a reporting witness, witness or expert witness, in accordance with the provisions of the applicable laws and regulations. Then the right of the community to obtain legal protection in order to carry out its participation is further regulated in Government Regulation Number 71 of 2000 concerning Procedures for Implementing Community Participation and Awarding in the Prevention and Eradication of Criminal Acts of Corruption. Chapter Three Rights and Responsibilities of the Community in Obtaining Legal Protection.

Specifically, the provision of legal protection for perpetrator witnesses (justice collaborator) is regulated in Joint Regulation Number: m.hh-11.hm.03.02.th.2011, Number: per-045/a/ja/12/2011, Number: 1 of 2011, Number kepb-02/01-55/12/2011, Number: 4 of 2011 concerning Protection for Whistleblowers, Reporting Witnesses and Collaborating Perpetrators. As stated that the witness who cooperates is entitled to: (a) physical and psychological protection, (b) legal protection, and (c) special treatment and (d) award.

After the revision of the Law on the Protection of Witnesses and Victims into Law Number 31 of 2014, Legal protection for justice collaborators was finally regulated in Article 10, which stipulates that a witness is a perpetrator (justice collaborator) as long as the testimony that will be, is being, or has been given is based on in good faith, he cannot be prosecuted either criminally or civilly. The phrase "good faith" requires that a person who gives a report and/or testimony to law enforcement is based solely on the desire to uncover a crime. However, if there is a lawsuit, the law enforcer is obliged to postpone it until the case for which he testifies has obtained permanent legal force. Why is that? First, so that justice collaborators can continue to focus on giving testimony in order to 
reveal the facts of a criminal act; Second, preventive measures do not let the lawsuits be an attempt by certain parties to hinder the process of examining cases that will be revealed.

\section{Special Handling}

Special handling prior to the revision of the Witness and Victim Protection Law is the right of the perpetrator's witnesses who cooperate as regulated in the Joint Regulation of the Minister of Law and Human Rights, the Attorney General, the Chief of the Indonesian National Police, the Corruption Eradication Commission and the Head of the Witness and Victim Protection Agency Number: m. hh-11.hm.03.02. th. 2011, Number: per-045/a/ja/12/2011, Number: 1 of 2011, Number kepb-02/01-55/12/2011, Number: 4 of 2011. The forms of handling specifically for justice collaborators include:

i. Separation of places of detention, confinement or imprisonment from suspects, defendants, and/or other convicts from the crimes disclosed in the event that the Witness of the cooperating perpetrator is detained or is serving a corporal punishment;

ii. Postponement of prosecution against him;

iii. Postponement of legal processes (investigations and prosecutions) that may arise due to the information, reports and/or testimony given; and/or

iv. Give testimony before the court without showing his face or without showing his identity. Then after the revision of the Witness and Victim Protection Law into Law Number 31 of 2014, special handling is regulated in Article 10 A which confirms that Perpetrator Witnesses can be given special treatment in the process of examining awards for the testimonies given, and special handling as referred to in paragraph (1) in the form of Separation of places of detention or places of imprisonment between Witness Perpetrators and suspects, defendants, and/or convicts whose crimes are revealed; Separation of filings between the Dossier's Witness file and the suspect's and defendant's files in the process of investigation and prosecution of the crimes they have disclosed; and/or testify in front of the trial without dealing directly with the defendant whose crime was revealed.

\section{Award}

Reward for justice collaborator is a form of reward given for the cooperation concerned in dismantling organized crime such as corruption. According to Lilik Mulyadi, that the award deserves to be given as an affirmation that the person concerned has contributed to law enforcement efforts. Based on the United Nations Convention Against Corruption, (2003) Article 37 regulates the award for cooperating perpetrator witnesses, including: Each participating country is obliged to consider, provide the possibility in certain cases to reduce the sentence of a actors who provide substantial cooperation in the investigation or prosecution of a corruption crime; Each participating country must consider the possibility in accordance with the basic principles of its national law to provide immunity from prosecution for persons who provide substantial cooperation in the investigation or prosecution (justice collaborator) of a criminal act of corruption. In Indonesia, the award for justice collaborators is regulated in Article 10A of Law Number 13 of 2006 in conjunction with Law Number 31 of 2014 concerning the Protection of Witnesses and Victims in the form of:

i. Relief of Criminal Imposition

To obtain an award in the form of leniency in imposing a criminal sentence, the LPSK provides a written recommendation to the public prosecutor to be included in his claim to the judge. Furthermore, the reward given to justice collaborators in corruption cases in the form of the severity of criminal sanctions is the domain of the Panel of Judges at the Corruption Court. For this reason, the Chief Justice of the Supreme Court of the Republic of Indonesia issued a Circular Letter of the Supreme Court (SEMA) Number U of 2014 concerning the Treatment of Criminal Whistleblowers (Whistleblowers) and Witnesses of Collaborating Perpetrators (justice collaborators) in Certain Criminal Cases.

ii. Granting Parole and Remission

The granting of remission and parole is regulated in Law Number 12 of 1995 concerning Corrections. Every prisoner has the right to get remission and parole. However, the granting of remission and parole still refers to the Government Regulation concerning the Terms and Procedures for the Implementation of the Rights of Correctional Inmates. Specifically for remission and parole for prisoners in corruption cases, currently there are at least 2 (two) regulations that regulate it, namely: Government Regulation of the Republic of Indonesia Number 28 of 2006 concerning Amendment to Government Regulation Number 32 of 1999 concerning Conditions and Procedures for the Implementation of Rights of Correctional Inmates ; Government Regulation of the Republic of Indonesia Number 99 of 2012 concerning the Second Amendment to Government Regulation Number 32 of 1999 concerning Terms and Procedures for the Implementation of the Rights of Correctional Inmates.

The issuance of the two Government Regulations is a conditional conditional through the Circular Letter of the Minister of Law and Human Rights issued on July 12, 2013. In the Circular it is emphasized that Government Regulation No. 99 of 2012 applies to convicts of corruption, narcotics, transnational crimes, terrorism, and human rights crimes whose criminal decisions have the power of attorney. permanent law after the date of ratification of Government Regulation Number 99 of 2012, namely November 12, 2012. Whereas those sentenced before November 12, 2012, the provisions in Government Regulation Number 28 of 2006 shall apply. 
Government Regulation Number 28 of 2006 confirms that "every prisoner and child has the right to get remission if he meets the requirements of good behavior and has served a criminal period of more than 6 months." For convicts who are convicted of committing crimes of terrorism, narcotics and psychotropic substances, corruption, crimes against state security and serious human rights crimes, and other transnational organized crimes, remission is given if they meet the requirements of good behavior and have served $1 / 3$ of the criminal period. As well as overall to prisoners and children doing actions that help prison activities.

In addition to the award in the form of remission, an inmate also gets parole. In the requirement to obtain parole based on Government Regulation Number 28 of 2006. The mechanism for obtaining awards in the form of granting remissions and/or parole for justice collaborators is carried out in accordance with the provisions of the Joint Regulation on Protection for Reporting Whistleblowers, Reporting Witnesses and Collaborating Actor Witnesses, namely the application submitted by the Co-operating Witness, Attorney General, KPK Leader and/or LPSK to the Minister of Law and Human Rights for later processing in accordance with applicable laws and regulations.

\section{Comparison of Justice collaborator Regulatory Laws in Different Countries}

Mulyadi (2016) stated that the practice of legal protection for justice collaborators has taken place in several countries, including:

\section{Justice Collaborator Arrangements in the United States}

In the United States, legal protection regulations for Whistleblowers and Justice collaborators are regulated in the Whistleblower Act 1989 which are oriented towards protection and dismissal, demotion, threats, temporary dismissal, harassment and discrimination. If detailed, actually the history of witness protection in the United States is an effort and the government to fight the mafioso who are already so dangerous that they disrupt national stability.

Witness protection was first carried out by the United States in the 1970s, which at that time "oath of silence" (omerta) was not shaken, thus threatening the lives of anyone who violated and cooperated with the police. Key witnesses could not be persuaded to testify and key witnesses disappeared because of the efforts of the leadership of the crime group targeted by the prosecution. This early experience convinced the United States Department of Justice that a witness protection program needed to be instituted.

The witness protection agency in the United States was first formed by a prosecutor named Gerarl Shur. Next, the United States, established a witness protection program with the regulation of the Witnes Security Reform Act in 1984 (Witnes Protection Act 1984). In this regulation, the United States provides protection for the physical safety of witnesses who are at risk through the placement of a new and confidential residence with a change of name and new identity details.

The 1984 Witness Security Reform Law is essentially oriented to the following dimensions:

i. Strict admission criteria, including an assessment of the risks to the community that may apply due to the relocation of the offender;

ii. Establishment of a budget to compensate victims and crimes committed by participants after being accepted into the program;

iii. The signing of a memorandum of understanding that outlines the witness's obligations after being accepted into the program;

iv. Development of procedures if the memorandum is violated by the participants;

v. Establishment of procedures for disclosing information on program participants and the penalties that apply to unauthorized disclosure of such information; and

vi. Protection of the rights of third parties, in particular respecting the debts of witnesses and the rights of representatives of parents who are not relocated or the rights of visits.

For a witness to be accepted into this program, the case in question is a very significant case, the testimony given by the witness needs to be of high value for a successful prosecution and there is no other alternative to physically securing the witness. Other conditions such as the witness's psychology and his ability to comply with the rules and restrictions set by the program were also a factor. In its development, acceptance of protection from mafia crimes has been expanded to also include witnesses from other organized crimes.

\section{Justice Collaborator Arrangements in the Netherlands}

The practice of protecting Justice collaborators in the Netherlands uses the mechanism of Witness Agreements, namely an agreement between the Public Prosecutor and a witness to give testimony with a reward. This witness provision is contained in the Dutch Criminal Procedure Code Title III, Section 4B-4D (Article 226 G-226 L PKC) since 2006. In Dutch criminal law there is a fairly sharp difference between physical protection and witnesses on the one hand, and on the other hand the instrument for make arrangements with witnesses to testify in exchange for rewards.

In the Netherlands witness agreements were not disputed until the 19th century. In those years much attention was paid to the fight against organized crime, on a broader scale and specifically the drug trade. In this fight, the police and the public prosecutor felt the need to use witness agreements to test possible witnesses to testify against their friend defendants. Actually, there is no legal basis 
for this, but the public prosecutor has the power to do so because he is acting on the principle of discretionary power. The Supreme Court gave its approval to this argument and thus indirectly allowed the Public Prosecutor to make promises to witnesses in exchange for testimony, although the Supreme Court asked the legislators to provide a more specific legal basis for the use of witness agreements.

However, due to various circumstances it lasted until 2006 before the witness agreement was included in the colonial criminal code procedure. Now the legal basis for such an agreement can be found in Book Two of the criminal code procedure title III section 4B/4D (article 226G-226L CCP). Furthermore, there is an important origin designation from the public power of attorney and attorney general's office which is called the briefing of promises to witnesses in criminal cases. This briefing contains more specific regulations regarding witness agreements and various aspects and should be respected as a guide line for the Public Prosecutor. This means, the judge may analyze whether the Prosecutor acted in accordance with this direction, and if not, the judge could declare this agreement invalid.

In the Dutch Witness Agreement, the Public Prosecutor is only allowed to make the agreement in cases of serious crimes, namely in cases of alleged criminal acts punishable by at least 8 (eight) years in prison or alleged crimes punishable by at least 4 (four) years in prison and which can be considered a serious organized crime (Article 226 G Nominal 1 CCP).

In the Netherlands, witnesses who make an agreement with the public prosecutor cannot testify anonymously. This is very important to ensure the physical protection of witnesses. Protection is provided by the Witness Protection Agency. When the Prosecutor is negotiating with the witness it may introduce it with the Witness Protection Service to assess the need for physical protection measures and the witness and sometimes some of his family members. J.H. Crijns further mentions in the witness agreement that the award or reward that can be given to the witness, in principle, is not allowed to give leniency greater than $50 \%$ of the sentence. This meant that it was impossible to grant waivers beyond the limit that would result in total freedom. In this dimension, the Dutch state witness agreement is very strict about it. This aspect does not mean that there are no other forms of compensation that can be offered to witnesses who are deemed to have agreed to the agreement with the Public Prosecutor. For example, it is permissible to claim illegally obtained profits. In addition to the aspects mentioned in the context above, the public prosecutor can offer all kinds of smaller rewards such as transfer to another prison closer to the witness's family.

\section{Justice Collaborator Arrangement in Germany}

The practice of witness protection in Germany was not initially carried out simultaneously. Witness protection has only been implemented throughout Germany since 1984. Following the implementation of witness protection. The first Witness Protection Office was established in Hamburg. Meanwhile, witness protection in Berlin was only implemented in 1984. The Office for Witness Protection in Berlin was established in 1989, as part of Crime Eradication and Organized Crime in the Police. The office of witness protection has existed for 12 years, before the publication of the Zeugenschutzgesetz/ZschG which regulates the Office of Witness Protection. To date, more than 100 witnesses have been enrolled in the witness protection program in Berlin.

Witness protection in Germany is regulated in two laws, namely the German Criminal Procedure Code (Strafprozessordnung/StPO), which in 1998 made special changes to the issue of witness protection through the Law on Protection of Witnesses in Criminal Processes and Protection of Victims ( Zeugenschtzgesetz/Zschc). This law emphasizes rights in the examination process. However, ZschGini does not take into account the rights of witnesses in particular, such as the rights of witnesses under threat, who are often key witnesses to serious crimes. In 2001 the German government passed the Law on the Harmonization of the Protection of Witnesses in Danger (Zeugenschutzharmonisierungsgezetz/ZshG). This law regulates the harmonization of state legislation on the protection of witnesses, and this law only regulates witness protection in general. In this Law, there is no distinction between witnesses and victim witnesses. And does not regulate the protection of witnesses who are reporting witnesses (whistleblower).

This Federal Law has been in effect since January 1, 2002. Witness protection is directly carried out by the state police themselves or other authorities. This ZshG was made with one of the objectives so that witnesses become the key to an extreme crime such as organized crime, for example terrorism. However, it is also possible for witnesses to other crimes to be included in the witness protection program specifically regulated in the law. For this reason, witnesses and their closest people must also be given protection. Witness protection is provided not only when giving testimony in court, but also involving witnesses and their closest people in the Witness Protection Program in extreme cases, which can take place during and after the trial process is over.

The Witness Protection Program includes efforts to relocate witnesses and their closest people, provide mental health therapy, provide temporary employment in the new place, provide living allowances, and others. In order for witnesses to be included in this witness protection program, the main requirement is that the crime committed is not a serious crime, without protection for witnesses it is difficult to prosecute the case. In Germany there is no special institution or special commission authorized to provide protection for witnesses . The handling of the provision of witness protection is carried out by the Office or Witness Protection Unit (Article 2 ZshG). Institutionally under the Inspectorate General of the German Police.

\section{Conclusion}

The urgency of providing legal protection for perpetrators of witnesses who are willing to cooperate with law enforcement in the investigation of Corruption Crimes is because Justice Collaborators are criminals who can help uncover a crime because they have 
the potential to have evidence to drag the main perpetrator and other suspects. 5.1.3. Arrangements for perpetrator witnesses who are willing to cooperate with law enforcement still cannot be used as a strong legal basis regarding the right to commutation of sentences for Justice Collaborators and have many weaknesses, especially in terms of commutation of sentences for Justice Collaborators for their testimony in assisting law enforcement officers but only as a consideration by judges. without a binding power that gives the judge an obligation to provide criminal leniency, therefore there needs to be a certain arrangement at all levels of the process of prosecuting criminal acts of corruption. The recommendation in this study is the need for a clear position for a Justice Collaborator in the process of law enforcement in cases of corruption and to provide certainty and justice. Law Number 31 of 2014 concerning Amendments to the Basis of Law Number 13 of 2006 concerning Protection of Witnesses and Victims and SEMA RI No. 14 of 2011 concerning the Treatment of Whistleblowers (Whistle Blowers) and Collaborating Perpetrators (Justice Collaborators) in Certain Criminal Acts and awarding a Justice Collaborator by giving him a reduced prison term.

\section{References}

Adji, I.S. (2009). Korupsi Kebijakan Aparatur Negara \& Hukum Pidana, Jakarta, Diadit Media.

Albanese, J.S. (2016). Kejahatan Terorganisasi (Organized Crime) Akar dan Perkembanganya. Jakarta, Prenadamedia group.

Alkostar, A. (2008). Korupsi Politik Di Negara Modern. Yogyakarta, FH UII Press,

Alt, J.E., and Lassen, D.D. (2010). Enforcement and Public Corruption: Evidence from US States. EPRU Working Paper Series. Available on https://web.econ.ku.dk/eprn_epru/Workings_Papers/wp-10-08.pdf

Amiruddin, and Asikin, Z. (2016). Pengantar Metode Penelitian Hukum. Jakarta, RajaGrafindo,

Atmasasmita, R. (2011). Sistem Peradilan Pidana Kontemporer. Jakarta, Kencana Prenada Media Group.

Husodo, A.T., et.al, (2016). Evaluasi dan Roadmap Penegakan Hukum KPK 2012-2015, Jakarta, Indonesia Corruption Watch. Available https://antikorupsi.org/sites/default/files/Evaluasi\%20\%26\%20Roadmap\%20Penegakan\%20Hukum\%20KPK\%202012.pdf Ibrahim, J. (2006). Teori \& Metodologi Penelitian Hukum Normatif. Jakarta, Bayumedia.

Ilyas, A.(2018). Justice Collaborator: Strategi Mengngkap Tindak Pidana Korupsi. Yogyakarta, Genta Publishing.

Institute for Criminal Justice Reform (ICJR). (2016). Problem Penetapan Bagi Pelaku Yang Bekerjasama Masih Terjadi di Pengadilan, Hakim dan Jaksa Masih Belum Sepakat Soal Status Pelaku Yang Bekerjasama, Available at https://icjr.or.id/problem-penetapan-bagi-pelaku-yang-bekerjasama-masih-terjadi-di-pengadilan-hakim-dan-jaksa-masihbelum-sepakat-soal-status-pelaku-yang-bekerjasama/

Manalu, R.Y. (2015). Justice Collaborator Dalam Tindak Pidana Korupsi. Lex Crimen, 4(1), 152-163. Available on https://ejournal.unsrat.ac.id/index.php/lexcrimen/article/view/7011/6516

Mulyadi, L. (2015). Perlindungan Hukum Whistleblower \& Justice Collaborator Dalam Upaya Penanggulangan Organized Crime. Bandung, Alumni.

Napitupulu, E. (2014). LPSK: Peran dan Pengalaman Penegak Hukum Terkait Perlindungan Saksi dan Korban untuk Beberapa Kasus (Hak Asasi Manusia, KDRT, TPPO dan Korupsi. Jurnal LPSK, 4(1). https://lpsk.go.id/publikasi/detailjurnal/2405

Pramono, R.W. (2016). Pemberantasan Korupsi dan Pidana Lainnya: Sebuah Perspektif Jaksa dan Guru Besar. Jakarta, Kompas Media Nusantara.

Semendawai, A.S. (2013). Memahami Whistleblower, Jakarta, LPSK RI.

Soekanto, S. (2012). Sosiologi Suatu Pengantar. Jakarta, PT Raja Grafindo. Persada.

Widjaya, F. (2012). Whistleblowers dan Justice Collaborator dalam Perspektif Hukum. Jakarta, Penaku

Publisher's Note: SSBFNET stays neutral with regard to jurisdictional claims in published maps and institutional affiliations.

\section{(a) (1)}

(C) 2021 by the authors. Licensee SSBFNET, Istanbul, Turkey. This article is an open access article distributed under the terms and conditions of the Creative Commons Attribution (CC BY) license (http://creativecommons.org/licenses/by/4.0/).

International Journal of Research in Business and Social Science (2147-4478) by SSBFNET is licensed under a Creative Commons Attribution 4.0 International License. 